\section{Perusteos vailla lisäarvoa}

\author{
Pekka Ruohotie (1996). Oppi- \\ malla osaamiseen ja menes- \\ tykseen. EDITA. 190 sivua.
}

$\mathrm{P}$ ekka Ruohotien kirjaa lukiessa tulee mieleen kirjakauppa, jossa myydään alan kirjallisuuden uusimpia ilmestyksiä. Kirjojen nimet sisältävät usein sanat: learning, competence, leadership, success tai teambuilding - juuri samoja aineksia kuin Ruohotien kirjassa. Näitä

kirjoja on tarjolla pilvin pimein ja ainakin omasta mielestäni aivan kyllästymiseen saakka. Tuoko Ruohotien kirja lisäarvoa alan tarjontaan?

Mikäli lukija jättää lukematta kirjan lukijalle osoitetun kappaleen, lisäarvoa ei ainakaan synny. Ruohotie toteaa lukijoilleen, että kyseessä on perusteos, johon on koottu alan perustietoa. Jos lukija ottaa vakavasti seuraavankin lauseen: “ ... jota ihmisten ja organisaatioiden ke-

hittämisestä vastuussa olevat asiantuntijat voivat hyödyntää tehtävässään...“, ei lisäarvoa synny. Kyseessä on todellakin vain perusteos tai oikeastaan hakuteos, jossa luetellaan hyvin pintapuolisesti ja kritiikittömästi erilaisia teorioita osaamisesta ja oppimisesta.

Alan ammattilainen tuskin löytää tästä kirjasta lisäarvoa työlleen: varsinaista uutta tietoa tai näkökulmaa kirjassa ei ole lainkaan. Teoksesta ei myös- kään löydy sellaista asioiden käsittelytapaa, joka auttaisi asiantuntijalukijaa kehittämään ajatteluaan tai toimintaansa aihepiirissä.

K irjan ikävin puoli on se, ettei se ole käytännönläheinen. Alan kirjojen laaja valikoima kaupan hyllyllä takaa, että teoreettista tietoa riittää. Lisäksi työyhteisöissä jokainen ihminen on tämän alueen asiantuntija. Tästä aiheesta voi painavan teorian esittää niin koneenkäyttäjä kuin kirjanpitäjäkin tai professori ja kaikki ovat yhtä oikeita. Mihin moni ei pysty on sellaisen toiminnan aikaansaaminen, joka saa nämä kaikki loistavat teoriat (jonkalaisia Ruohotienkin esittämät ajatukset toki ovat) toimimaan käytännössä ja tuottamaan tulosta, joka kantaa pitkälle tulevaisuuteen.

Oppivan organisaation teorian toteuttamista kuvataan lähinnä "pitää luoda oppimista tukeva infrastruktuuri" -tyyppisillä triviaaleilla tokaisuilla.

K irjassa painotetaan myös paljon arviointia ja tarkkailua... jokainen käytännön organisaationkehittämis- laatu-, tai johtamistyötä tehnyt tietää, että arvioimalla ja tarkkailemalla ei synny toivottua tulosta... Peter Koestenbaumin toteamus, että businesta ei tehdä tuloksen vuoksi vaan busineksen vuoksi, eli hyvä prosessi, jossa arviointi on implisiittisenä - piilorakenteena, tuottaa hyvän tuloksen.

$\mathrm{D}$ inosaurusten ajassa ollaan, kun esimiehille annetaan käytännön 'vinkkinä’ ohje käyttää suunnitteluun paljon aikaa ja sitoa eri sidosryhmät suunnitelmaan.
Nykyaikaisessa organisaationkehittämistyössä toteutetaan enemmänkin demingläistä Plan (learn) - Do - Study - Act - ohjelmaa, jossa kaikki ihmiset osallistuvat kehittämisvision ja suunnitelman tekemiseen sekä niiden toteuttamiseen, jopa samanaikaisesti suunnitelman kanssa. Näin toimien ei ketään tarvitse sitoa mihinkään, sillä siihen mitä on itse ollut mukana luomassa, haluaa myös olla toteuttamassa.

Täkemys henkilöstöstä eri1 laisten toimenpiteiden kohteena on niin ikään vanhanaikaista. Henkilöstöä kehittämällä, kouluttamalla ja perehdyttämällä saavutetaan tuloksia. Kymmenvuotisen kokemukseni pohjalta voin todeta, että ihmiset eivät halua olla minkään kohteita, vaan aktiivisia toimijoita ja itsenäisiä oman kasvunsa johtajia. Tällaisena Ruohotiekin ihmiskäsityksensä ilmaisee, mutta muussa tekstissä tämä ihmiskäsitys ei saa tukea.

\aiken kielteisyyden päätZteeksi haluan todeta, että kirjassa ei suinkaan ole mitään varsinaisesti virheellisiä asioita. Mitään yksittäistä kohtaa ei voi osoittaa sormella ja todeta se täysin vääräksi, vaan pikemminkin päinvastoin; kaikki kirjassa esitetty on oikein ja toimivaa, sovellettuna oikeassa paikassa oikeaan aikaan ja sopivina annoksina.

Olennaista organisaation kehittämistyössä ja oppimisprosesseissa näyttäisikin olevan tietynlainen pragmatismi: kaikki mikä toimii, on hyvää, ja mikä ei toimi, se pitää vaihtaa. Kun oppimisessa ja osaamisessa on kysymys ihmisistä ja heidän vä- 
lisestä vuorovaikutuksestaan on oppimisen vapaus aivan rajaton. On mahdollista kokeilla, muuttaa mielipidettä ja saada uusia vaikutteita. Erehdykset ovat äärimmäisen harvoin kohtalokkaita.

\ikään ei ole niin joustava 1 kuin ihminen. Meidän alamme ihmisten ei pitäisi pyrkiä kahlitsemaan ihmisiä järjestelmiimme, niin loistavia ja teoreettisesti pitäviä kuin ne olisivatkin. Meidän on sen sijaan keskityttävä auttamaan ihmisiä ja organisaatioita löytämään mahdollisuutensa ja tukemaan heidän omia kehitysprosessejaan mahdollisuuksien tehokkaaksi hyödyntämiseksi.

Cristina Andersson 